Max-Planck-Institut für demografische Forschung Max Planck Institute for Demographic Research Konrad-Zuse-Strasse 1 - D-18057 Rostock - GERMANY

Tel +49 (0) 3812081 - 0; Fax +49 (0) 3812081 - 202;

http://www.demogr.mpg.de

MPIDR WORKING PAPER WP 2004-001

JANUARY 2004 (REVISED MARCH 2004)

\title{
Women's labor force attachment and childbearing in Finland
}

Andres Vikat (vikat@demogr.mpg.de)

This working paper has been approved for release by: Jan M. Hoem (hoem@ demogr.mpg.de)

Head of the Laboratory of Contemporary European Fertility and Family Dynamics.

(C) Copyright is held by the authors.

Working papers of the Max Planck Institute for Demographic Research receive only limited review. Views or opinions expressed in working papers are attributable to the authors and do not necessarily reflect those of the Institute. 


\title{
Women's Labor Force Attachment and Childbearing in Finland
}

\author{
Andres Vikat \\ Max Planck Institute for Demographic Research \\ Konrad-Zuse-Straße 1 \\ D-18057 Rostock, Germany \\ vikat@demogr.mpg.de
}

\begin{abstract}
This paper analyzes the impact of women's economic activity, earnings and take-up of child home care allowance on childbearing, using a ten percent sample from a longitudinal register data set that covers the entire female population of reproductive age in Finland in 1988-2000. Results show that a woman's economic activity and income were positively correlated with entry into motherhood and to a lesser extent with having a second child. This supports the notion of a common pattern of this relationship in the Nordic countries. In the light of Finland's rollercoaster economic development in the 1990s, the effects of a change in female population composition by economic characteristics on the fertility trend were small.
\end{abstract}




\section{Introduction}

The relationship between women's labor-force participation and fertility is one of the most extensively studied areas in fertility research (for overviews, see, e.g., Bernhardt 1993, Brewster \& Rindfuss 2000). Many demographic studies on this subject have been published that focus on the Nordic countries, in the main on Sweden and Norway. In this study, I look at the impact of women's labor-force attachment and childbearing in Finland. This analysis contributes to our understanding of whether there is a discernible Nordic pattern to this relationship and highlights some features specific to Finland.

\subsection{Theoretical considerations}

Most studies on the relationship between women's labor-force participation and fertility consider in some form the micro-economic rational choice theory of the New Home Economics that links childbearing probabilities to the levels of direct and opportunity costs of childbearing. It assumes that the gender division of work and family life is economically beneficial to the family if incompatibility exists between labor-force participation and motherhood (Becker 1993). The assumption that gender-specific division of work and family life are favorable to the family has been criticized on the grounds that it entails considerable risks to the well-being of the family. If one of the adult members of such a family cannot fully perform his or her functions, well-being and even survival of the family is at risk, and therefore, a dual-earner family would be a more adaptive family strategy in a modern nuclear family system (Oppenheimer 1994). In recent decades, differences between the labor-market roles of men and women have been narrowing, and the incompatibility between employment and childbearing has been decreasing in countries that have adopted various policies to this end (Bernhardt 1993, Blossfeld 1995).

Cumulative evidence from numerous empirical studies suggest that the theory of New Home Economics does not provide an all-encompassing general explanation for the relationship between labor-market activity and childbearing (for a summary of critique, see, e.g., van de Kaa 1996). Nevertheless, the main mechanisms that it suggests to be the link between women's labor-force participation and fertility, namely the price-of-time effect and the income effect, serve as important theoretical considerations for building hypotheses on childbearing in a certain socio-cultural context. The price-of-time effect implies that childbearing incurs opportunity costs in the form of foregone income and human capital accumulation, while the income effect implies that higher earnings help the couple to cope with the direct costs of childbearing and childrearing. In case of a clear-cut gender division of work and family life, the price-of-time effect would dominate among women: Those with higher earning potential would have a lower 
childbearing probability, while the income effect would dominate among men, their higher earnings leading to higher childbearing probabilities. As the labor-market and family roles of men and women have become increasingly similar over time, it is far from clear whether the price-of-time effect really dominates among women. A general hypothesis is that the less incompatible employment and childbearing are, the smaller the price-of-time effects; and the smaller the differences between the wages of men and women, the larger the income effect for women.

The theoretical underpinnings vary by birth order. Given that voluntary childlessness is not very common in the Nordic countries, the question of when? would dominate in a couple's considerations about becoming a parent, while the question of Whether or not to have another child? would be more pertinent to considering a second and especially a third child. Hence, an important element in considering entry into parenthood is that its opportunity costs depend on its timing in relation to a woman's education and employment career. The life-course setting for progressions to higher-order births is shaped by the timing of entry into parenthood, birth spacing and reaching the two-child norm.

Economic theories mainly deal with the constraint side of childbearing while they say little about the motivation why people have children, given their net positive costs. Friedman, Hechter and Kanazawa (1994) presented a theory of the value of children, proposing that uncertainty reduction is the underlying motivation for having children. While not intending to follow their assumption on uncertainty reduction as a universal immanent value underlying transition to parenthood, I take uncertainty reduction as one of the elements against which a woman's decision about whether and when to have a first child can be weighed. Friedman, Hechter and Kanazawa (1994) claim that the impetus for parenthood is greatest among those whose alternative pathways for reducing uncertainty are limited or blocked. In this study, a low level of education combined with unemployment can be viewed as limited possibilities of reducing uncertainty through an employment career.

\subsection{The Finnish context}

Finland is one of the Nordic countries characterized by a universalistic type of welfare state that provides relatively generous public support to families with children. Both the level and type of this support reduce the incompatibility between labor-force participation and childbearing more so than other types of welfare states do and it is also geared towards greater gender equality (Esping-Andersen 1990). During the last two decades, the Nordic countries have had relatively high fertility in the European context, with the Total Fertility Rate above 1.6. The welfare state characteristics of these countries have been viewed as contributing to this (see e.g., Bernhardt 
1993, Hoem 1993, Ellingsæter \& Rønsen 1996, Brewster \& Rindfuss 2000). On the whole, the changes in period fertility levels in Northern and Western Europe were typically not major ones in the 1980s and 1990s, at least when compared to the 1960s and 1970s. Still, volatile reactions of fertility levels to social policy measures and economic cycles have been shown for Sweden (Hoem 1993, Andersson 2000, Hoem 2000). In Finland, the period Total Fertility Rate reached a high point of 1.74 in 1983, then decreased to 1.59 in 1987, it rose to 1.85 in 1992 and 1994, and reached another low of 1.70 in 1998 . The fluctuations were notably smaller in Finland than in Sweden and Denmark during the same periods, and about the same size order as in Norway (Vikat 2002) (Figure 1).

\section{Figure 1}

In the first half of the 1990s, Finland was struck by a heavy economic recession. Although the Finnish welfare state on the whole retained its functions (Heikkilä \& Uusitalo 1997), marked changes took place in various spheres of life. Disposable incomes decreased as tax rates rose; some benefits, including parenthood allowance, were reduced, and eligibility requirements for housing support were tightened. The unemployment rate increased from $3 \%$ in 1990 to $16 \%$ in 1993, and among 15-24 year-old women from 8\% to 31\% (Statistics Finland 2003). This development was accompanied by an increase in perceived job insecurity (Nätti et al 2001). The recession affected the well-being of families with children through various pathways (Forssén 1999, Hiilamo 2002). The post-recession recovery in the middle and second half of the 1990s witnessed labor-market developments that decreased the compatibility between work and family life, such as a trend towards increasing temporary work contracts, particularly among women and in younger age groups (Salmi \& Lammi-Taskula 1999). Work also became mentally increasingly wearing as time pressures rose, new work organization practices demanded stronger commitment from employees and the latter became increasingly motivated to perform well given the general insecurity on the employment market (Lehto \& Sutela 1999).

Differently to Sweden where Andersson (2000) demonstrated a pro-cyclical pattern of the fertility trend, there has been no obvious correlation between the volatile macro-economic trends and overall fertility level in Finland. On the contrary, the highest total fertility rates in Finland over the last 30 years were recorded during the economic recession in the first half of the 1990s (Vikat 2002). These macro-level observations warrant looking for distinct features of the Finnish case in the Nordic context.

The key features we need to consider about Finnish policies aimed at reconciliation of women's labor-force participation and family life are support for a dual-earner family (for a European comparison, see Korpi 2000), a high level of maternity and parental-leave allowances and their 
long period of payment (see Salmi \& Lammi-Taskula 1999), and a high level of day care services (for an international comparison, see Gauthier 1996). The size of the parental-leave allowance is calculated as $70 \%$ of the level of earnings of last tax year or of last six months, with step-by-step decrease of this income-replacement percentage in higher income brackets. The take-up rate among women is over 90\% (Salmi \& Lammi-Taskula 1999).

Other Nordic countries largely share these characteristics (Rønsen \& Sundström 2002). In the mid-1980s, the introduction of child home care allowance (HCA) in Finland led to a substantial difference to the other Nordic countries as it was an element that did not support a dual-earner family (see e.g., Sipilä 1995, Ilmakunnas 1997, Sipilä \& Korpinen 1998, Salmi \& LammiTaskula 1999, Hiilamo 2002 for details and discussions about implications of this policy measure). It provides an opportunity to stay at home taking care of one's own children that are under three years of age, to receive an allowance and be entitled to return to one's job. The allowance is paid if the child is not in public childcare. The amount of the fixed allowance varied in the 1990s from about 250 to $310 €$ per month, with a means-tested supplement and a possible municipality supplement. In 1998, a similar policy was introduced in Norway (Rønsen 2001).

Sipilä \& Korpinen (1998) emphasized the policy's importance during the economic recession of the early to mid-1990s: The introduction of HCA led to favorable conditions for childbearing and rearing as an attractive alternative to existing or impending unemployment in the background of shrinking opportunities in the labor market. Note that until 1993, it was possible to receive HCA and unemployment benefits simultaneously. Until late into 1995, a family with at least one parent employed was eligible for HCA. Thereafter, it was no longer possible to receive HCA if a family member received unemployment benefit. HCA was raised in 1991 by a third of its original sum, followed by a small reduction in 1995 and a 23\% reduction in 1997. Also, the number of municipalities that paid their own additional contributions to HCA decreased in the mid-1990s (Korpinen 1997, Salmi \& Lammi-Taskula 1999).

The Finnish fertility trends, particularly that of second and higher order births, have parallel features with the increase and decrease in the percentage of families taking up HCA and in the size of the allowance itself. The onset of the increase in fertility in 1987 took place when HCA was gaining momentum, and second and higher order births continued to increase after the 1991 rise in allowance (Vikat 2002).

\subsection{Earlier studies on the Nordic countries}

Several studies on the Nordic countries point out that where high public provisions for combining childbearing and employment depend on the level of earnings, the relationship between women's labor-market attachment and childbearing does not follow the direction 
typically suggested by economic theory. In Sweden, entry into motherhood was found to be positively correlated with women's earnings (Andersson 2000, Hoem 2000). This result mainly has been interpreted in the light of the income replacement feature of parental-leave allowances and increasingly similar labor-market and family roles of men and women in Sweden. These developments contribute to the similarity between the effects of women's and men's labormarket characteristics on a couple's fertility (Andersson, Duvander and Hank 2004). In both Sweden and Norway, first-birth risk has also increased with women's work experience (Kravdal 1994, Hoem 2000, Santow \& Bracher 2001). On the whole, the effects of economic variables on second and third-birth risks have been less strong than on first births (Hoem \& Hoem 1989, Kravdal 1992b, Berinde 1999, Andersson 2000).

Previous studies on the effects of women's unemployment on childbearing in Nordic countries have not provided conclusive evidence in either a positive or negative direction. According to Andersson (2000) and Hoem (2000), earnings-related unemployment benefits count in determining eligibility for an income replacement type of parental-leave allowance and this is one of the explanations for the slightly elevated propensity of unemployed women in Sweden to become a mother. Kravdal (2002) arrived at the same result in Norway, concluding that due to the many possible sources of spuriousness of this relationship, a large effect of any sign seems unlikely. Regarding second and third-birth propensities in both Norway and Sweden, women's unemployment has only a small influence, not leading to a clear conclusion of the sign of the effect (Andersson 2000, Kravdal 2002).

This study does not focus on women's level of education. However, one of the reasons for including it as a control variable is to analyze variation in the effects of activity-related variables by education level, in view of its relationship with the long-term capacity of earning a higher income. It is also evident that building up this capacity in terms of prolonged education would postpone the age at which highly educated women become mothers (Note 1). Kravdal (1994) showed that a woman's level of education has only little influence on first-birth risks in Norway when her earnings are accounted for. For Finland, Finnäs (1995) estimated that married women with tertiary education had a higher propensity to give birth to a second child, while among cohabiting women the association was the opposite; Ruokolainen \& Notkola (2002) showed that Finnish mothers with tertiary education who have two children are more likely to aim at having a third child than those with less education. In many models on other countries, the effect of the education level on second and third births appears positive (Hoem \& Hoem 1989, Kravdal 1992a, 2001, Kreyenfeld 2002), which may seem going counter with the general conjecture that women with a high level of education have fewer children. Hoem (1996), Kravdal (2001) and 
Kreyenfeld (2002) have demonstrated that such effects can be explained by age at education completion, by selectivity, and, in the West German case, also by the partner's level of education (Kreyenfeld 2002).

\subsection{Hypotheses}

In this paper, I analyze the relationship between women's labor-market attachment and childbearing in Finland over the period from 1988 to 2000. I also examine the possible changes in these relationships and their role in maintaining the relatively stable fertility level throughout the 1990s when Finland went through sharply contrasting stages of business cycle. In addition, I look at the relationship between using the child home care allowance introduced in Finland in the late 1980s and a woman's subsequent childbearing. Since Finland shares the basic features of its family-related social policies with the other Nordic countries, it should not be surprising to find the same kind of relationships between labor-market activity and childbearing as in Sweden and Norway. Based on earlier studies and the characteristics of the Finnish context, I put forward the following hypotheses:

Nordic family formation pattern hypothesis. The income replacement character of parental-leave allowance and the general value orientation towards a dual-earner family lead most women to complete their education and gain eligibility to these benefits and a certain acceptable level of income before they plan to have the first child. Therefore, first-birth rates increase with income and are very low for women in education.

Woman's income effect hypothesis. Through a contribution to the total family income, a woman's higher income helps couples to cope with the costs of rearing a two-child family and speed up the attainment of the two-child norm. A positive income gradient is expected in the risk of second births.

Uncertainty reduction hypothesis. The impetus for parenthood is greatest among those whose alternative pathways for reducing uncertainty are limited or blocked. Women with poor prospects in the labor market have an elevated first-birth risk because they seek uncertainty reduction by motherhood, which brings order and stability to the life course. Other women, by contrast, reduce uncertainty through their work career and for them motherhood would not mean uncertainty reduction to the same extent.

Childcare leave hypothesis. Women who make use of extended childcare leave related to HCA are either more family-oriented than those who do not take up this benefit or they do not have high career aspirations. This is manifested in their higher propensity to have a second and third child. It does not imply that HCA as a policy measure itself has a fertility-increasing effect. 


\section{Data and Method}

\subsection{Data}

I use data from the Finnish Longitudinal Fertility Register, a Statistics Finland database that contains linked individual-level information from different administrative registers. The extract used in my analysis includes women's full histories of childbearing and educational attainment, with events recorded to precision of the month, and a range of annually measured characteristics about their activity and income. Data on births and education cover a woman's entire life span until the end of the year 2000. A consistent set of annually measured characteristics of activity and income can be constructed for the period from 1987 to 2000. Since I use the activity and income of a certain year to explain childbearing during the following year, the study period includes the years 1988 to 2000 . This period includes the years of economic recession as well as some years before and after that recession, so that fertility behavior in different macro-level contexts can be compared.

The register extract is a ten-percent random sample stratified by single-year birth cohort, drawn from records of all women who had ever received a personal identification number in Finland and were in the age range 20 to 44 at least for some time during 1988 to 2000 (cohorts born from 1944 to 1980). Foreign-born women (three percent) were excluded from the analyses, because the cultural and structural contexts in which immigrants experience family formation and childbearing may have been substantially different from that of women born in Finland, and I do not intend to analyze the differences between immigrant and the native population in this study. The analysis focuses on the age range 20 to 44 . Family formation before age 20 is not common in Finland. Only three percent of all children are born to women of that age (Council of Europe 2003) and most teenage births are probably unplanned. Births to teenagers primarily reflect adolescent sexual behavior, failure in preventive activities and, when pregnant, the acceptance of early pregnancy, whereas the hypotheses of this study assume planned childbearing. In addition, the characteristics of individual employment and educational career carry a different meaning in adolescence than they do at more advanced ages; measures of the parental home not available for this study would have been more appropriate to describe their economic background (see Vikat et al 2002). The analysis thus includes Finnish-born women aged 20 to 44 who had less than three children (fourth and higher-order births are not analyzed) for at least some time during the observation period. There were 125,392 such women in the data, and they had 28,955 first, 25,869 second and 12,934 third births during the observation period (Table 1).

The large-scale register data set used in this study ensured the representation of the entire female population of the country and sufficient statistical power for presenting meaningful differences, 
while keeping a bias from reporting errors and non-response minimal. These are significant advantages over survey data of similar nature.

\section{Table 1}

\subsection{Study variables}

The event under study is a live birth, and the intensity of its occurrence is analyzed as the dependent variable, measured with a month's precision. I take into account that there is a delay between the time the decision to have a child is taken and the time a child is born, and that the explanatory variables should be measured close to the time when these decisions have supposedly been taken. The explanatory variables are measured as summary information about a calendar year or status at the end of a calendar year and thus it is appropriate to keep referring to the time when the child was actually born, and use the explanatory information for the previous year in the models (Note 2). All explanatory variables used in the models are time-varying.

I disregard information on marriage and marital partners that is available in the register, primarily because having only information on marriages and no information on consensual unions would not allow a consistent analysis of the effect of a partner's characteristics on a couple's childbearing. In Finland, $22 \%$ of all couples and $17 \%$ of couples with children live in a consensual union (Statistics Finland 2004), and 40\% of all children are born outside marriage (Council of Europe 2003). As information on the start and end months of consensual unions and characteristics of unmarried partners will be incorporated into the register database in the future, it may be possible to consider these aspects in future studies. This study is thus based on the characteristics of women only.

The distribution of births and person-years under risk by the study variables is presented in Table 1. Information on activity is recorded as main activity at the last week of the year based on different register sources. In constructing the status measure at the end of the year, Statistics Finland gave first priority to determine a person's belonging to the labor force, and within the labor force, unemployment was determined before employment (Statistics Finland 2000). This definition influences the way students appear in the classification, in particular, because the main activity of those students who also have a job is determined as employed in this data set, while in an interview study many of them would define themselves as students (Statistics Finland 2000). In our sample, students are defined as persons who are engaged in full-time studies in an education institution and who are not employed.

A woman on maternity or parental leave at the end of the year is normally registered as employed. However, if no record of actual work as an employee during the entire calendar year 
is available, she is put into the category non-active which includes all women about whom there is no information in the register on employment, unemployment or studies. Women who are on childcare leave (the extended leave related to HCA) appear in the category non-active if they have not worked as employees at any time during that year.

A woman's main activity, one of the important explanatory variables used in this study, is measured at the end of a calendar year. This gives rise to the question to what extent this crosssectional measure characterizes her status over a longer period of time - this could be assumed to have an influence on childbearing behavior. To complement the cross-sectional data on activity status at the end of a calendar year with information on the extent to which this applies to the whole year, I also use the total number of months a woman appeared as employed and the number of months she was unemployed in the last calendar year as explanatory variables in the models.

Measures of income include the total taxable income, unemployment benefits, parental-leave allowance and child home care allowance (HCA) for a calendar year. Earnings were approximated from this information by subtracting the amounts of the taxable benefits from the total taxable income. The amounts were transformed into 1995 values, using the consumer price index, and cut-point values for the $33^{\text {rd }}, 66^{\text {th }}$ and $95^{\text {th }}$ percentile were obtained from the 1995 distribution (4,800 €, 16,000 € and 28,100 €, respectively). These values were then used to put women into categories of no, low, medium, high, and highest income brackets throughout the study period. In most models, women in the highest income category did not differ from those whose earnings were between the $66^{\text {th }}$ and $95^{\text {th }}$ percentile significantly, and in these models the two categories were joint into one. The information on whether a woman received HCA is used as an indicator of having taken up this additional option some time during a calendar year.

The highest attained level of education was updated in the follow-up according to the recorded month in which a woman completed the higher level of education. The register includes a record of all education levels that exceeded compulsory schooling (9-10 years). In this study, the level of education is grouped as follows: lower secondary (no education after compulsory schooling), upper secondary (11-12 years), lower tertiary (13-15 years) and upper tertiary education (16-18 years). This reflects the way the Finnish educational system is structured (Repo 1997) and allows for a sizable proportion of women in each category.

In order to analyze the net relationship of the economic and policy variables with fertility, I control for the woman's age measured in single-year age groups and calendar year measured as a categorical variable. To analyze the differences in the effects by stage of the business cycle, I used a categorical period variable that distinguished the pre-recession (1987-1990), recession 
(1991-1994) and post-recession (1995-2000) years. In models of second and third births age of youngest child is used as another control variable. In these models, exposure to the birth risk starts when the youngest child is ten months old, and age of youngest child is included as a categorical variable with a month's precision until 17 months of age, in three-month groups of 18 to 20 and 21 to 23 months, in six-month groups from 24 to 59 months, and in completed years up to 10 or more years.

\subsection{Statistical analysis}

I analyze the data with intensity-regression (proportional hazard) models with piecewise constant specification of the baseline intensity, using the GLIM software package (Aitkin et al 1989). As described above, information on activity and income is updated at the end of each calendar year, whereas births, highest level of education, mother's age, age of youngest child, and censoring due to emigration or death are known on a monthly basis. The economic variables are updated so that the status of the year $t-1$ (income, total number of months employed and unemployed, HCA take-up) or at the end of the year $t-1$ (activity) is used to explain childbearing risk in year $t$. Observations are censored at the month of death, at first emigration, at age 45, or at the end of the year 2000, whichever came first.

Models are fitted separately for the risk of a first, second and third lifetime birth. Since earlier studies have revealed that patterns of entry into motherhood vary substantially with age (see e.g., Vikat 2002), I fitted separate models of first birth for 20 to 30 year-old and 31 to 44 year-old women. For each birth order, I present results from basic models that include the control variables - age, age of youngest child and calendar year - and one other study variable at a time. This is followed by the presentation of Model 1 that simultaneously includes main activity, earnings, and level of education in addition to the demographic control variables. Model 2 additionally includes the count of months in employment and in unemployment in the previous calendar year where they are statistically significant. Experiments with several categorical specifications of the number of months revealed that the assumption of a linear change of birth risk by number of months is justified.

Models on HCA take-up focus on the period when women were eligible for HCA in the previous calendar year. Here, exposure to the birth risk starts in January of the year during which the youngest child becomes two years old - so that the mother could be entitled to HCA in the previous calendar year as far as her youngest child's age is concerned - and ends when the child becomes four. Since the birth risk increases strongly during the youngest child's second year and the relationship between HCA take-up and birth risk could also be expected to vary during this time, age of youngest child is included by month's precision. 
I checked the interactions of activity, earned income and level of education and report on them whenever any meaningful interactions were found. Finally, I also examined the influence of compositional factors on the time trends of fertility, by comparing birth risks by calendar year obtained from different models. Results are presented in the form of relative risks, which are exponentiated values of regression coefficients.

\section{Results}

\subsection{First births}

Among 20 to 30 year-old women the relative first-birth risks by activity status show that fulltime education inhibits childbearing in Finland, with the first-birth risk of women who study being less than half of the risk of employed or unemployed women (Table 2). Non-active women also displayed a low rate of entry into motherhood compared to the employed and unemployed. When estimated from a model that includes age and calendar year only (Basic Model), 20 to 30 year-old unemployed women had the same propensity to become a mother as employed women did; however, the unemployed had a notably higher relative risk when earnings and education level were controlled for. In addition, the interaction of activity status and level of education was significant and meaningful (not shown). The higher risk of entry into motherhood only applied to unemployed women who did not have more than a compulsory level of education. Among them, the relative first-birth risk of the unemployed compared to the employed was 1.26; at all other education levels, employed and unemployed women had the same level of first-birth risk. Unemployed women with lower secondary education had the highest risk among all combined categories by activity and level of education of 20 to 30 year-old women.

\section{Table 2}

The number of months registered as employed or unemployed rendered significant additional information on the activity status recorded at the end of the year (Table 2). The first-birth risk of 20 to 30 year-old women increased on average by $3.1 \%$ each month of employment during the previous year, and by $5.8 \%$ each month of unemployment. This is consistent with the pattern of relative risks by activity status measured at the end of the year, namely, with higher first-birth risks of employed and unemployed women compared to others, and with higher risks for the unemployed compared to the employed. It shows that the longer duration spent in these statuses, the more distinctively its effect appeared.

The results showed a strong positive effect of a 20 to 30 year-old woman's earnings on her propensity to become a mother, also after controlling for the level of education. A relatively little variation by level of education in 20 to 30 year-old women's propensity to becoming a mother 
was noticeable; however, there was a highly significant and meaningful interaction. Among women with a compulsory level of education only, income did not matter at all regarding firstbirth risk, while there was a very clear income gradient among women with more education (Table 3). Noticeably, among younger childless women with a low level of education the lack or low level of earnings did not inhibit entry into motherhood, while it clearly did among women of same age with an education higher than a compulsory one. This finding is consistent with the results described above on the elevated first-birth risks of young unemployed women with a low education level, showing that young women who may face poor long-term prospects in the labor market are not less likely to enter motherhood.

\section{Table 3}

Among women over age 30, being in employment, having higher earnings and a higher level of education were all positively correlated with transition to motherhood. As the relative risks in Table 4 show, the association of these variables with the first-birth risk of 31 to 44 year-old women was different from that observed among younger women. Of the four activity categories, women who did not participate in the labor force and did not study had the lowest risk.

Employed women had the highest risk, and the risk of unemployed women was a little lower. Among 31 to 44 year-old women, the first-birth risk increased by $0.9 \%$ per each month of employment registration in the previous calendar year, while the number of months unemployed did not have a significant effect.

The large income effect estimated from the basic model, according to which women at the highest third of the income distribution had twice the first-birth risk of the women in the lowest third, is to some extent explained by activity and level of education. When controlled for these two variables, the high-income earners still displayed a higher risk, but only by $38 \%$.

\section{Table 4}

\subsection{Second and third births}

As shown in connection with entry into parenthood, women who studied also had a lower risk of second and third birth (Tables 5 and 6). The size order of the relative risk these women faced was the same in the models for second and third births and in the models of first births to 31 to 44 year-olds, while the inhibiting effect of studies was largest among younger childless women. The other contrasts by activity status and earnings were also smaller in second and third-birth risks than in first-birth risks. Women who were neither participating in the labor force nor studying had a slightly elevated risk of second and third birth. Unemployed women faced the same second-birth risk as employed women did, whereas their third-birth risk was higher than 
that of the employed and at the same level with the non-active women. Second-birth risk increased by months in employment and by months in unemployment during the previous calendar year. The third-birth risk was only related to the number of months unemployed.

\section{Tables $5 \& 6$}

Results revealed a positive effect of earnings on second-birth risks, although it was much weaker than that on first-birth risks. An analysis of the interactive effects showed that the moderate income gradient existed only for those women who had taken more than a compulsory education (not shown). As with the 20 to 30 year-old women's entry into motherhood described above, income was not related to second-birth risk among women who had compulsory education only.

With third-birth risks there was no difference between the broad income categories that were presented in the models of first and second births. The only income effect in third-birth risks concerned a moderately elevated risk of those in the highest five percent of the income distribution, all others being equal. The positive gradient of second and third-birth risks by level of education was almost as large as that in the first-birth risk of 31 to 44 year-olds, and insensitive to the inclusion of activity and income in the model.

The take-up of HCA was related to a higher risk of third birth. Women who had received any amount of this allowance in a preceding calendar year faced an $18 \%$ higher risk of third birth compared to those who did not receive this allowance. There was no difference in second-birth risks by HCA take-up, however. Figure 2 presents the birth risks by age of youngest child and HCA take-up. The elevated third-birth risk of HCA recipients appears only when the second child is about two and a half years old (Figure 2). When it is younger, those who drew HCA and those who did not had about equal third-birth risks.

Figure 2

\subsection{Change in the composition by and in the effects of economic variables}

Two systematic changes in the effects of explanatory variables over time pertain to 20 to 30 year-old women's transition to motherhood. In the post-recession period after 1994, first-birth risks of employed women were $15 \%$ lower than before, while there was virtually no change in first-birth risks in other activity categories (not shown; these effects are controlled for earned income and level of education). First-birth risks also decreased among 20 to 30 year-old women with a medium or higher income, by $18 \%$ and $9 \%$, respectively, while there was almost no change among women with no or low income (controlled for activity and level of education). In Figure 3, the trend curves estimated from a model with only demographic control variables (age, and age of youngest child where applicable) are compared to curves that are adjusted for 
both demographic and economic variables. Although there was a considerable change in the composition of the female population by activity status and income, this had a small influence only on the parity-specific fertility trend, as the relative risks by calendar year estimated from models with and without the economic variables were close to each other.

Figure 3

The most important compositional change with respect to the economic variables was the increase and subsequent decrease in the number of unemployed women. The small influence of this on the trend can primarily be explained by the small size of fertility differences between the employed and unemployed women. There was also some change in the distribution of women by earnings. During the recession the number of women in the low and no income categories increased and that in the high-income category decreased; this was followed by the opposite development after the recession. Income effects were largest among childless women in the twenties; however, precisely in this group the unemployed women also had a higher first-birth risk, and on aggregate the compositional effects of unemployment and income offset each other to some extent. For first and second births, the curve adjusted for economic variables ran slightly higher in the mid-1990s than the unadjusted one, thus indicating that the composition by economic variables slightly depressed the birth risks in that period. In the case of third births, this small compositional effect was positive. This can be understood in the light of the higher risk of unemployed mothers with two children to have a third child and in the light of the virtually non-existent income gradient in third-birth risks.

\section{Discussion}

The key findings of this study are as follows:

- A woman's earnings have a positive effect on her giving birth to a first and second child in Finland.

- On the whole, her unemployment has a weak relationship with childbearing risks.

- The take-up of child home care allowance (HCA) is related to a higher risk of third birth but not to a second-birth risk.

- Changes in the distribution of the female population by activity and income do not have a major influence on parity-specific fertility trend in Finland.

What do we learn from this with regard to the Nordic family formation pattern hypothesis? A major finding of this study is the clear positive relationship between a woman's earnings and her first and second-birth risks. Evidence from Norway and Sweden (Kravdal 1994, Andersson 
2000, Hoem 2000) suggests that there is a common Nordic pattern characterized by a positive correlation between labor-market attachment and first and second-birth risks. My results by earnings and activity are notably close to the ones obtained for Sweden by Andersson (2000), those on younger women's entry into parenthood in particular. It was clear both in this study and in earlier ones on Sweden and Norway that women in the labor force have a higher propensity to become a mother than non-active women. The current research also confirmed that enrolment in education is incompatible with childbearing, which seems to be a universal finding in all studies that have used enrolment as a time-varying covariate.

The positive relationship between earnings and entry into motherhood may seem to contradict the notion that women who command a higher wage have lower childbearing risks because of the high opportunity cost of childbearing, which is an argument stemming from economic theory. In the Nordic context, it seems that women's wage rate or earnings would not reflect economic opportunity costs in the same way as in other countries, in particular because the size of the compensation paid during parental leave in the Nordic countries is calculated as a high percentage of earnings. The availability of publicly subsidized childcare is another pillar reducing opportunity costs for women. The data available for this study included information on earnings and not on wage rates, the latter which would be a more direct measure of a child's opportunity cost for women. However, based on the information on earnings alone, the effects are so strong, that they would hardly be challenged by data on wage rates.

Since only few women prefer to remain childless in Finland (Nikander 1998), most women would look for a suitable point in time for the transition to motherhood. From an economic point of view, a stable job with reasonable income provides such a context. In that context, the opportunity costs would largely be set off by welfare benefits while the family as a whole is in a better position to cope with the direct costs of childbearing. This would mean that the income effect is dominating among women through the significant contribution they make to the total family income. As with the other Nordic countries, the system of wages and individual taxation favors the dual-earner family in Finland, so that the woman's income is usually an important pillar in ensuring an acceptable living standard. A detailed analysis of the relative importance of the price-of-time and income effects for men and women can be conducted using data on partners. However, it is quite clear from this study that a woman's transition to motherhood, and to a lesser extent, progression to the second child are more likely to occur to women who are employed and have relatively high earnings. This would not be the case if the price-of-time effect would dominate. 
The slight decrease in first-birth risks among younger employed women and younger women with higher earnings after 1994 when compared to the stable level of transition to motherhood among other women may be interpreted in the light of a trend towards increasing temporary work contracts and mentally more wearing work (Salmi \& Lammi-Taskula 1999, Lehto \& Sutela 1999). This decreases the compatibility of work and family life. Since the decrease in the propensity to become a mother only pertained to women below age 30, increasing labor-market insecurities at the early stages of the working career would be another plausible interpretation. Based on earlier research, I expected the effects of economic variables to be stronger for entry into motherhood than for births of higher order. Mainly, because entry to parenthood is a life transition of more crucial importance than the transitions to higher order parities (Hobcraft \& Kiernan 1995). Having made this transition, parents of one child face normative pressure to have a second child after a short interval (Note 3 ) in the context of a two-child norm.

Among mothers of two children, no positive correlation between attachment to the labor market and the birth risk was evident, which is consistent with previous Finnish findings on childbearing intentions based on survey data (Ruokolainen \& Notkola 2002). The selected group with the highest earnings had a relatively high risk of third birth, while, by contrast, non-active and unemployed women were more likely to proceed to a third child than the employed. Here, one needs to consider that women who are at risk of a third birth have demonstrated their susceptibility to have children by having had two, which may be selective among the higher educated with high income (Kravdal 2001, Kreyenfeld 2002). Once women in the highest income category have two children and wish to have a third, they have less economic constraints than other women.

The results that young women with a low education level are more likely to become a mother when they are unemployed and that low income does not inhibit their entry into motherhood can be interpreted in the light of the uncertainty reduction hypothesis. While most women in the Nordic countries can be assumed to aim at gaining a foothold in their working career before becoming a mother by studying first and then advancing in employment, women with a low education level who consider their labor-market prospects as poor may want to anchor themselves into parenthood earlier than their counterparts. One may think here of a kind of alternative life strategy of women with a low education level who are not studying and who are unemployed. Women with little education and poor prospects in the labor market may seek uncertainty reduction in motherhood, which brings order and stability to the life course, whereas other women may reduce uncertainty through their work career. 
In my analysis, the above described pattern only pertained to childless women up to age 30, while above that age unemployment inhibited motherhood. The meaning of unemployment presumably differs at the different stages of a woman's employment career. Unemployment is usually higher among younger people who are making their first work experience. At a more advanced stage, however, unemployment may have more of a disturbing influence on one's life and at that stage a woman would wait with motherhood until the discontinuity in her working career is settled. We can think of a selection process that lies behind the age difference in the effect of unemployment: those who assessed their long-term employment prospects as low and opted for relatively early parenthood can be assumed to have done so before age 30, while most women who remain childless beyond that age would like to pursue a working career and would be more likely to consider motherhood when having a stable job.

The results showed that women who make use of extended childcare leave related to HCA have a higher propensity to have a third child - possibly and primarily because women who are relatively child and family oriented opt for HCA as part of their plan to have a third child. Ruokolainen \& Notkola (2002) have found that women with traditional family values are more likely to aim at having a third child. The opportunity to stay at home when having young children can be assumed to be consistent with such values. The availability of HCA may indeed help these women to realize their plans of having three children. An additional interpretation, namely that staying at home to care for children is in itself an experience that influences childbearing plans of having a third child, is also plausible. This is because the elevated thirdbirth risk of HCA recipients emerged after a woman had been on childcare leave for some time, that is, when the second child was in its third year of life: the third child born at that time having been conceived during childcare leave if used. The lack of any relationship between HCA takeup and second-birth risk may be explained by the fact that having a second child is the dominant behavior for one-child mothers and that there may be little room for the influence of HCA takeup. Note that this study did not explicitly test whether the introduction of HCA had a fertilityincreasing effect; a study with simultaneous modeling of HCA take-up and childbearing risk that compares periods before and after its introduction would be needed.

This analysis found that women's labor-market attachment in Finland is an important determinant of their entry into motherhood. To a lesser extent it also explains the rate of second and third births: advancement in one's employment career could stimulate these parity transitions. A discernible influence of rollercoaster economic cycles on childbearing was not evident, however. Of the various aspects of compositional changes, increase in unemployment was the largest, but since unemployment did not have a large influence on childbearing risks, this 
compositional change did not have a notable impact on the overall fertility trend. The subjective perception of economic prospects may also have an impact on childbearing behavior. People may postpone childbearing at a time they consider as economically difficult and also when those who are in employment have fears - whether real or perceived - about a possible deterioration of their economic situation. These aspects were not directly measured in this study, but the results indicate that such effects could not have been large in Finland.

Evidently, if the recession brought along an anticipation of economic hardship, this did not have a notable influence on childbearing plans of Finnish women. Two explanations can be offered:

First, the belief in an economic recovery that would start soon probably shaped the assessment of long-term economic prospects when making childbearing plans. Second, as the Finnish welfare state was able to retain its important functions during the recession in spite of notable cuts in some spheres, the assessment of the economic recession as a temporary state of affairs may have induced some women to take time out of employment precisely during that time when possibilities for advancement in working career were unfavorable, possibly also considering the availability of extended childcare leave linked to HCA.

This study is the first one that uses the recently compiled longitudinal register data set mentioned above, and it concentrates on the basic relationship between women's labor-market attachment and childbearing, with the aim to highlight the features of the relationship common to the Nordic countries. Childbearing plans and decisions are not made solely by women and one would need to examine the socio-economic and demographic characteristics of both partners to obtain a more detailed picture of the mechanisms that link employment characteristics with childbearing. This information would allow researchers in particular to analyze the gender-specificity of the various effects of economic variables. Another aspect that needs to be addressed in future studies is that of selectivity. Earlier studies have shown that the large fertility-increasing effects of women's education attainment arise in part from the fact that women at different education levels differed in the duration between education completion and childbirth (Hoem 1996). Also, women with high education who start having children have a higher score on an unobserved fertilityproneness parameter than other women (Kravdal 2001, Kreyenfeld 2002). Future research on fertility in Finland should preferably address these aspects with joint modeling of births of different order and by including parameters for unobserved heterogeneity. This paper provides a good starting point for such studies. 


\section{Acknowledgments}

I would like to thank Statistics Finland for the permission to use their data set (permission TK53118 03), Timo Nikander and Seija Öörni for consultations on the related definitions and technicalities, Gunnar Andersson and Hill Kulu for comments and discussions on earlier versions of this paper, and Susann Backer for language editing.

\section{Notes}

1. Blossfeld \& Huinink (1991) have demonstrated the importance of this aspect in explaining fertility differentials by women's level of education.

2. The results of this study are in many respects compared to those for Sweden by Andersson (2000) and Hoem (2000) who used the same kind of data setup.

3. In the data of this study, $39 \%$ of Finnish women at age 44 have two children and $65 \%$ have two or more; the interval between the first and second birth was on the average 31 months; cohort parity progression ratios from parity one to parity two ranged from $70 \%$ to $80 \%$ for the cohorts included in this study (Frejka \& Calot 2001).

\section{References}

Aitkin M, Anderson D, Francis B, Hinde J 1989. Statistical Modelling in GLIM. Oxford Statistical Science Series. Oxford University Press

Andersson G 2000. The impact of labour-force participation on childbearing behaviour: Pro-cyclical fertility in Sweden during the 1980s and the 1990s. European Journal of Population 16 (4): 293-333

Andersson G, Duvander A-Z, Hank K 2004. Erwerbsstatus und Familienentwicklung in Schweden aus Paarbezogener Perspektive [The impact of the labor-market attachment of fathers and mothers on continued childbearing in Sweden]. In: Hank K, Tölke A (eds.) Das ,vernachlässigte' Geschlecht in der Familienforschung: Untersuchungen zu Partnerschaft und Elternschaft bei Männern [Sonderheft 4 der Zeitschrift für Familienforschung]. Opladen: Leske + Budrich. Forthcoming

Becker GS 1993. A Treatise on the Family. Cambridge, Massachusetts: Harvard University Press

Berinde D 1999. Pathways to a third child in Sweden. European Journal of Population 15: 349-378

Bernhardt E 1993. Fertility and employment. European Sociological Review 9: 25-24

Blossfeld H-P (ed.) 1995. The New Role of Women: Family Formation in Modern Societies. Boulder: Westview Press

Blossfeld H-P, Huinink J 1991. Human capital investments or norms of role transition? How women's schooling and career affect the process of family formation. American Journal of Sociology 97 (1): 143-168.

Brewster KL, Rindfuss RR 2000. Fertility and women's employment in industrialized nations. Annual Review of Sociology 26: 271-296

Council of Europe 2003. Recent demographic developments in Europe: 2002. Strasbourg: Council of Europe

Ellingsæter AL, Rønsen M 1996. The dual strategy: motherhood and the work contract in Scandinavia. European Journal of Population 12: 239-260

Esping-Andersen G 1990. The Three Worlds of Welfare Capitalism. Princeton: Princeton University Press

Finnäs F 1995. Entry into consensual unions and marriages among Finnish women born between 1938 and 1967. Population Studies 49: 57-70

Forssén K 1999. Families with children in recessionary Finland. Yearbook of Population Research in Finland 35 (1998-1999): 145-157

Frejka T, Calot G 2001. Cohort reproductive patterns in the Nordic countries. Demographic Research [online] 5 (5), available at http://www.demographic-research.org/Volumes/Vol5/5/5-5.pdf

Friedman D, Hechter M, Kanazawa S 1994. A theory of the value of children. Demography 31 (3): 375-401 
Gauthier A 1996. The State and the Family: A Comparative Analysis of Family Policies in Industrialized Countries. Oxford: Clarendon Press

Heikkilä M \& Uusitalo H (eds) 1997. The Cost of Cuts. Studies on Cutbacks in Social Security and Their Effects in the Finland of the 1990s. Helsinki: STAKES

Hiilamo H 2002. The Rise and Fall of Nordic Family Policy? Historical Development and Changes During the 1990s in Sweden and Finland. STAKES Research Report 125. Helsinki: STAKES

Hobcraft J, Kiernan KE 1995. Becoming a parent in Europe. Welfare State Programme Discussion Paper WSP 116. London: London School of Economics Research Laboratory

Hoem B 1993. The compatibility of employment and childbearing in contemporary Sweden. Acta Sociologica 36: 101-120

Hoem B 1996. The social meaning of the age at second birth for third-birth fertility: A methodological note on the need to sometimes respecify an intermediate variable. Yearbook of Population Research in Finland 33: 333339.

Hoem B 2000. Entry into motherhood in Sweden: The influence of economic factors on the rise and fall in fertility, 1986-1997. Demographic Research [online] 4 (2), available at http://www.demographicresearch.org/Volumes/Vol2/4/2-4.pdf

Hoem B, Hoem JM 1989. The impact of women's employment on second and third births in modern Sweden. Population Studies 43 (1): 47-67.

Hoem JM 1993. Public policy as a fuel of fertility: Effects of a policy reform on the pace of childbearing in Sweden in the 1980s. Acta Sociologica 36: 19-31

Ilmakunnas S 1997. Public policy and childcare choice. In: Persson I \& Young C (eds), Economics of the Family and Family Policies. London: Routledge

Korpi W 2000. Faces of inequality: Gender, class, and patterns of inequalities in different types of welfare states. Social Politics 7 (2): 127-191.

Korpinen J 1997. Lasten kotihoidon tuki ja sen muutokset 1990-luvulla [Children's home care allowance and how it has changed in the 1990s]. Helsinki: KELA

Kravdal $\varnothing 1992 \mathrm{a}$. The emergence of a positive relation between education and third birth rates in Norway with supportive evidence from the United States. Population Studies 46 (3): 459-475.

Kravdal Ø 1992b. The weak impact of female labour force participation on Norwegian third-birth rates. European Journal of Population 8:247-263.

Kravdal $\varnothing 1994$. The importance of economic activity, economic potential and economic resources for the timing of first births in Norway. Population Studies 48: 249-267

Kravdal Ø 2001 The high fertility of college educated women in Norway: An artefact of the separate modelling of each parity transition. Demographic Research 5 (6): 187-215

Kravdal Ø 2002. The impact of individual and aggregate unemployment on fertility in Norway. Demographic Research [online] 6 (10): 263-294, available at http://www.demographic-research.org/Volumes/Vol6/10

Kreyenfeld M 2002. Time-squeeze, partner effect or self-selection? An Investigation into the positive effect of women's education on second birth risks in West Germany. Demographic Research [online] 7 (2): 15-48, available at http://www.demographic-research.org/Volumes/Vol7/2

Lehto H-M, Sutela H 1999. Efficient, More Efficient, Exhausted: Findings of Finnish Quality of Work Life Surveys 1977-1997. SVT. Labour Market 1999:8. Statistics Finland. Available at http://www.stat.fi/tk/el/efficient_77_97.pdf

Nikander T 1998. Fertility and Family Surveys in Countries of the ECE Region. Standard Country Report: Finland. New York, Geneva: United Nations

Nätti J, Kinnunen U, Happonen M, Mauno S, Sallinen M. Perceived job insecurity among Finnish employees in 1990-2000: Prevalence and antecedents. Pp 484-506 in Kalela J, Kiander J, Kivikuru U, Loikkanen HA, Simpura J (eds.), Down from the Heavens, Up from the Ashes: The Finnish Economic Crisis of the 1990s in the Light of Economic and Social Research. VATT Publications 27:6. Helsinki: Government Institute for Economic Research (VATT). Available at http://www.vatt.fi/julkaisut/julkaisu.asp?id=309

Oppenheimer VK 1994. Women's rising employment and the future of the family in industrial societies. Population and Development Review 20 (2): 293-342

Repo A 1997. Register of Completed Education and Degrees. Helsinki: Statistics Finland

Rønsen M 2001. Market work, child care and the division of household labour: Adaptations of Norwegian mothers before and after the cash-for-care reform. Reports 2001/3. Oslo: Statistics Norway. Available at http://www.ssb.no/emner/03/04/30/rapp_200103/rapp_200103.pdf

Rønsen M, Sundström M 2002. Family policy and after-birth employment among new mothers - A comparison of Finland, Norway and Sweden. European Journal of Population 18: 121-152

Ruokolainen A, Notkola I-L 2002. Familial, situational, and attitudinal determinants of third-birth intentions and their uncertainty. Yearbook of Population Research in Finland Vol 38: 179-206

Salmi M, Lammi-Taskula J 1999. Parental leave in Finland. Pp 85-121 in Moss P, Deven F (eds.), Parental Leave: Progress or Pitfall? NIDI CBGS Publications 35. The Hague/ Brussels: NIDI/ CBGS

Santow G, Bracher M 2001. Deferment of the first birth and fluctuating fertility in Sweden. European Journal of Population 17 (4): 343-363. 
Sipilä J 1995. The right to choose: Day care for children or money for parents. Pp 151-169 in Page R, Baldock J (eds.), Social Policy Review 6. Canterbury: Social Policy Association

Sipilä J, Korpinen J 1998. Cash versus child care services in Finland. Social Policy \& Administration 32 (3): 263 277

Statistics Finland 2000. Economic Activity and Housing Conditions of the Population 1950-1995. Population Census 1995: Volume 3. Official Statistics of Finland. Helsinki: Statistics Finland

Statistics Finland 2003. Statistics online [cited 4 Dec 2003]

Statistics Finland 2004. Statistics online [cited 11 Feb 2004] http://tilastokeskus.fi/tk/he/tasaarvo_perheet.html

Van de Kaa DJ 1996. Anchored narratives: The story and findings of half a century of research into the determinants of fertility. Population Studies 50 (3): 389-432

Vikat A 2002. Fertility in Finland in the 1980s and 1990s: Analysis of fertility trend by age and parity. Yearbook of Population Research in Finland Vol 38: 159-178

Vikat A, Rimpelä A, Kosunen E, Rimpelä M 2002. Socio-demographic differences in the occurrence of teenage pregnancies in Finland in 1987-1998: A follow-up study. Journal of Epidemiology \& Community Health 56 (9): 659-668 
Table $1 \quad$ Distribution of births and person-years under risk by study variables

\begin{tabular}{|c|c|c|c|c|c|c|c|c|c|}
\hline \multirow[t]{4}{*}{ Variables } & \multicolumn{9}{|c|}{ Parity } \\
\hline & \multicolumn{3}{|c|}{ Zero } & \multicolumn{3}{|c|}{ One } & \multicolumn{3}{|c|}{ Two } \\
\hline & \multirow{2}{*}{$\begin{array}{r}\text { First } \\
\text { births }\end{array}$} & \multicolumn{2}{|c|}{ Person-years } & \multirow[t]{2}{*}{ Second births } & \multicolumn{2}{|c|}{ Person-years } & \multirow[t]{2}{*}{ Third births } & \multicolumn{2}{|c|}{ Person-years } \\
\hline & & Count & $\%$ & & Count & $\%$ & & Count & $\%$ \\
\hline \multicolumn{10}{|l|}{ Age } \\
\hline $20-24$ & 8,367 & 172,187 & 39 & 3,923 & 14,673 & 8 & 778 & 4,921 & \\
\hline $25-29$ & 12,323 & 118,605 & 27 & 10,076 & 36,810 & 19 & 3,467 & 30,510 & 10 \\
\hline 30 & 1,785 & 16,499 & 4 & 2,187 & 9,049 & 5 & 1,135 & 11,197 & \\
\hline $30-34$ & 6,179 & 66,941 & 15 & 8,569 & 44,772 & 23 & 5,348 & 70,193 & 24 \\
\hline $35-39$ & 1,797 & 44,857 & 10 & 2,877 & 44,467 & 23 & 2,834 & 90,402 & 31 \\
\hline $40-44$ & 289 & 39,585 & 9 & 424 & 50,083 & 26 & 507 & 100,313 & 34 \\
\hline \multicolumn{10}{|c|}{ Age of youngest child } \\
\hline $10-11$ months & & & & 97 & 4,928 & 3 & 34 & 4,393 & \\
\hline 1 year & & & & 7,188 & 27,401 & 14 & 2,277 & 25,747 & \\
\hline 2 years & & & & 7,641 & 19,396 & 10 & 2,581 & 23,603 & \\
\hline 3 years & & & & 4,054 & 13,792 & 7 & 1,967 & 21,752 & \\
\hline 4 years & & & & 2,074 & 11,016 & 6 & 1,549 & 20,296 & 7 \\
\hline 5 years & & & & 1,227 & 9,577 & 5 & 1,156 & 19,096 & \\
\hline 6 years & & & & 841 & 8,676 & 5 & 837 & 18,174 & \\
\hline $7-9$ years & & & & 1,515 & 22,304 & 12 & 1,459 & 49,956 & 17 \\
\hline 10 or more yrs. & & & & 1,232 & 73,715 & 39 & 1,074 & 113,322 & 38 \\
\hline \multicolumn{10}{|l|}{ Calendar year } \\
\hline 1988 & 2,321 & 35,009 & 8 & 2,163 & 17,519 & 9 & 1,022 & 22,074 & 7 \\
\hline 1989 & 2,312 & 35,179 & 8 & 2,089 & 17,156 & 9 & 1,084 & 25,778 & \\
\hline 1990 & 2,394 & 35,121 & 8 & 2,134 & 16,810 & 9 & 1,040 & 25,679 & \\
\hline 1991 & 2,400 & 34,832 & 8 & 2,074 & 16,208 & 8 & 1,117 & 25,470 & \\
\hline 1992 & 2,467 & 34,354 & 8 & 2,203 & 15,643 & 8 & 1,152 & 24,752 & \\
\hline 1993 & 2.353 & 33.712 & 8 & 2.073 & 15,160 & 8 & 1,111 & 23.951 & \\
\hline 1994 & 2,386 & 33,275 & 8 & 2,137 & 14,648 & 8 & 982 & 23,303 & \\
\hline 1995 & 2,150 & 33,098 & 7 & 2,007 & 14,168 & 7 & 1,025 & 22,660 & \\
\hline 1996 & 2,121 & 33,248 & 8 & 1,930 & 13,673 & 7 & 966 & 21,554 & \\
\hline 1997 & 2,072 & 33,423 & 8 & 1,937 & 13,055 & 7 & 869 & 21,044 & \\
\hline 1998 & 1,968 & 33,570 & 8 & 1,733 & 12,646 & 7 & 813 & 20,689 & \\
\hline 1999 & 2,042 & 33,620 & 8 & 1,680 & 12,208 & 6 & 889 & 20,026 & \\
\hline 2000 & 1,969 & 33,733 & 8 & 1,709 & 11,912 & 6 & 864 & 19,361 & \\
\hline \multicolumn{10}{|l|}{ Activity } \\
\hline employed & 22,017 & 280,441 & 63 & 17,210 & 140,449 & 74 & 8,437 & 229,956 & 78 \\
\hline unemployed & 3,420 & 44,845 & 10 & 2,581 & 18,995 & 10 & 1,424 & 25,521 & 9 \\
\hline studying & 2,596 & 88,503 & 20 & 1,347 & 9,778 & 5 & 435 & 9,799 & \\
\hline non-active & 922 & 28,385 & 6 & 4,731 & 21,583 & 11 & 2,638 & 31,063 & 10 \\
\hline \multicolumn{10}{|l|}{ Earnings } \\
\hline none & 970 & 19,082 & 4 & 3,262 & 16,546 & 9 & 1,953 & 23,242 & 8 \\
\hline low & 4,100 & 107,498 & 24 & 5,941 & 31,569 & 17 & 2,847 & 43,339 & 15 \\
\hline medium & 13,267 & 189,661 & 43 & 10,633 & 75,613 & 40 & 4,725 & 112,425 & 38 \\
\hline high * & 9,340 & 108,418 & 25 & 5,276 & 58,675 & 31 & 2,945 & 102,057 & 34 \\
\hline very high * & 1,278 & 17,515 & 4 & 757 & 8,401 & 4 & 464 & 15,276 & \\
\hline \multicolumn{10}{|l|}{ Level of education } \\
\hline lower secondary & 3,433 & 60,983 & 14 & 3,827 & 48,298 & 25 & 2,460 & 70,841 & 24 \\
\hline upper secondary & 13,231 & 237,087 & 54 & 11,474 & 84,698 & 44 & 5,875 & 131,212 & 4 \\
\hline lower tertiary & 9,488 & 113,700 & 26 & 8,158 & 46,427 & 24 & 3,618 & 77,004 & 26 \\
\hline upper tertiary & 2,803 & 30,405 & 7 & 2,410 & 11,382 & 6 & 981 & 17,282 & \\
\hline Received HCA ** & & & & & & & & & \\
\hline no & & & & 5,550 & 16,789 & 34 & 1,532 & 18,414 & 30 \\
\hline yes & & & & 11,370 & 32,469 & 66 & 4,555 & 42,358 & \\
\hline Total & 28955 & 442174 & 100 & 25869 & 190805 & 100 & 12934 & 296338 & \\
\hline
\end{tabular}

Note: In the statistical analyses I used data to a month's precision. The person-years in this table are rounded to the nearest integer.

* In the models of first and second births, the two highest categories of earnings were merged into one.

** In the models, exposure to the birth risk starts in January of the year during which the youngest child becomes two years old - so that the mother could be entitled to HCA in the previous calendar year as far as her youngest child's age is concerned - and ends when the child becomes four. Hence the numbers of births and person-years summed over this variable are smaller than the totals over the other variables in the table. 
Table 2 Relative first-birth risks of 20 to 30 year-old women by activity, earnings and level of education

\begin{tabular}{|c|c|c|c|c|c|c|c|}
\hline \multirow[t]{2}{*}{ Variable } & \multirow[t]{2}{*}{ Category } & \multicolumn{2}{|c|}{$\begin{array}{c}\text { Basic Models } \\
\text { (separate model for each } \\
\text { listed variable) }\end{array}$} & \multicolumn{2}{|r|}{ Model 1} & \multicolumn{2}{|r|}{ Model 2} \\
\hline & & $\begin{array}{l}\text { Relative } \\
\text { risk }\end{array}$ & $\begin{array}{c}95 \% \\
\text { confidence } \\
\text { interval }\end{array}$ & $\begin{array}{l}\text { Relative } \\
\text { risk }\end{array}$ & $\begin{array}{l}95 \% \text { confidence } \\
\text { interval }\end{array}$ & $\begin{array}{l}\text { Relative } \\
\text { risk }\end{array}$ & $\begin{array}{l}95 \% \text { confidence } \\
\text { interval }\end{array}$ \\
\hline \multirow[t]{4}{*}{ Activity } & employed & 1 (ref.) & & 1 (ref.) & & 1 (ref.) & \\
\hline & unemployed & 1.08 & 1.03 to 1.12 & 1.23 & 1.18 to 1.29 & 1.12 & 1.06 to 1.19 \\
\hline & studying & 0.40 & 0.38 to 0.42 & 0.49 & 0.46 to 0.51 & 0.59 & 0.56 to 0.63 \\
\hline & non-active & 0.62 & 0.58 to 0.67 & 0.70 & 0.65 to 0.76 & 0.91 & 0.83 to 0.99 \\
\hline \multirow{4}{*}{ Earnings } & none & 1.33 & 1.23 to 1.44 & 1.08 & 1.00 to 1.17 & 1.00 & 0.92 to 1.08 \\
\hline & low & 1 (ref.) & & 1 (ref.) & & 1 (ref.) & \\
\hline & medium & 1.66 & 1.59 to 1.72 & 1.31 & 1.26 to 1.37 & 1.27 & 1.22 to 1.33 \\
\hline & high & 2.06 & 1.97 to 2.16 & 1.53 & 1.45 to 1.61 & 1.46 & 1.38 to 1.55 \\
\hline \multirow{4}{*}{$\begin{array}{l}\text { Level of } \\
\text { education }\end{array}$} & lower secondary & 1 (ref.) & & 1 (ref.) & & 1 (ref.) & \\
\hline & upper secondary & 0.72 & 0.69 to 0.75 & 0.76 & 0.73 to 0.80 & 0.79 & 0.75 to 0.82 \\
\hline & lower tertiary & 0.91 & 0.87 to 0.95 & 0.87 & 0.83 to 0.91 & 0.90 & 0.86 to 0.94 \\
\hline & upper tertiary & 0.90 & 0.85 to 0.96 & 0.87 & 0.82 to 0.93 & 0.96 & 0.90 to 1.02 \\
\hline \multicolumn{2}{|c|}{ Months employed } & & & & & 1.031 & 1.026 to 1.036 \\
\hline \multicolumn{2}{|c|}{ Months unemployed } & & & & & 1.058 & 1.050 to 1.066 \\
\hline
\end{tabular}

Notes:

1. Basic Models include the woman's age, calendar year, and the variables in the table one at a time.

2. Model 1 includes the woman's age, calendar year, activity, earnings, and level of education.

3. Model 2 includes the woman's age, calendar year, and all variables in the table. 
Table 3 Interaction effect of earnings and level of education on the first-birth risk of 20 to 30 year-old women

\begin{tabular}{lcccc}
\hline Earnings & \multicolumn{5}{c}{$\begin{array}{c}\text { Level of education } \\
\text { (compulsory) }\end{array}$} & Above compulsory level \\
\cline { 2 - 6 } none & $\begin{array}{c}\text { Relative } \\
\text { risk }\end{array}$ & $\begin{array}{c}95 \% \text { confidence } \\
\text { interval }\end{array}$ & $\begin{array}{c}\text { Relative } \\
\text { risk }\end{array}$ & $\begin{array}{c}95 \% \text { confidence } \\
\text { interval }\end{array}$ \\
low & 1.11 & 0.97 to 1.28 & 0.65 & 0.58 to 0.72 \\
medium & 1 (ref.) & & 0.51 & 0.47 to 0.56 \\
high & 1.12 & 1.02 to 1.23 & 0.91 & 0.84 to 0.99 \\
\hline
\end{tabular}

Note: The model also includes the woman's age and calendar year. 
Table $4 \quad$ Relative first-birth risks of 31 to 44 year-old women by activity, earned income and level of education

\begin{tabular}{|c|c|c|c|c|c|c|c|}
\hline \multirow[t]{2}{*}{ Variable } & \multirow[t]{2}{*}{ Category } & \multicolumn{2}{|c|}{$\begin{array}{c}\text { Basic Models } \\
\text { (separate model for each } \\
\text { listed variable) }\end{array}$} & \multicolumn{2}{|r|}{ Model 1} & \multicolumn{2}{|c|}{ Model 2} \\
\hline & & $\begin{array}{l}\text { Relative } \\
\text { risk }\end{array}$ & $\begin{array}{c}95 \% \\
\text { confidence } \\
\text { interval }\end{array}$ & $\begin{array}{l}\text { Relative } \\
\text { risk }\end{array}$ & $\begin{array}{l}\text { 95\% confidence } \\
\text { interval }\end{array}$ & $\begin{array}{l}\text { Relative } \\
\text { risk }\end{array}$ & $\begin{array}{l}95 \% \text { confidence } \\
\text { interval }\end{array}$ \\
\hline \multirow[t]{4}{*}{ Activity } & employed & 1 (ref.) & & 1 (ref.) & & 1 (ref.) & \\
\hline & unemployed & 0.71 & 0.64 to 0.78 & 0.89 & 0.79 to 0.99 & 0.93 & 0.83 to 1.05 \\
\hline & studying & 0.57 & 0.49 to 0.66 & 0.67 & 0.57 to 0.78 & 0.71 & 0.60 to 0.83 \\
\hline & non-active & 0.33 & 0.29 to 0.38 & 0.46 & 0.40 to 0.54 & 0.50 & 0.42 to 0.59 \\
\hline \multirow{4}{*}{ Earnings } & none & 0.99 & 0.84 to 1.18 & 1.12 & 0.94 to 1.33 & 1.12 & 0.94 to 1.34 \\
\hline & low & 1 (ref.) & & 1 (ref.) & & 1 (ref.) & \\
\hline & medium & 1.37 & 1.23 to 1.53 & 1.18 & 1.05 to 1.32 & 1.15 & 1.02 to 1.29 \\
\hline & high & 1.98 & 1.78 to 2.20 & 1.38 & 1.23 to 1.56 & 1.33 & 1.17 to 1.51 \\
\hline \multirow{4}{*}{$\begin{array}{l}\text { Level of } \\
\text { education }\end{array}$} & lower secondary & 1 (ref.) & & 1 (ref.) & & 1 (ref.) & \\
\hline & upper secondary & 1.60 & 1.46 to 1.76 & 1.40 & 1.27 to 1.54 & 1.40 & 1.27 to 1.54 \\
\hline & lower tertiary & 2.09 & 1.90 to 2.29 & 1.68 & 1.53 to 1.85 & 1.69 & 1.53 to 1.86 \\
\hline & upper tertiary & 2.41 & 2.18 to 2.67 & 1.90 & 1.71 to 2.12 & 1.93 & 1.73 to 2.15 \\
\hline \multicolumn{2}{|c|}{ Months employed } & & & & & 1.009 & 1.000 to 1.018 \\
\hline
\end{tabular}

Notes:

1. Basic Models include the woman's age, calendar year, and the variables in the table one at a time.

2. Model 1 includes the woman's age, calendar year, activity, earnings, and level of education.

3. Model 2 includes the woman's age, calendar year, and all variables in the table. 
Table $5 \quad$ Relative second-birth risks by activity, earnings and level of education

\begin{tabular}{|c|c|c|c|c|c|c|c|}
\hline \multirow[t]{2}{*}{ Variable } & \multirow[t]{2}{*}{ Category } & \multicolumn{2}{|c|}{$\begin{array}{c}\text { Basic Models } \\
\text { (separate model for each } \\
\text { listed variable) }\end{array}$} & \multicolumn{2}{|r|}{ Model 1} & \multicolumn{2}{|r|}{ Model 2} \\
\hline & & $\begin{array}{l}\text { Relative } \\
\text { risk }\end{array}$ & $\begin{array}{c}95 \% \\
\text { confidence } \\
\text { interval }\end{array}$ & $\begin{array}{l}\text { Relative } \\
\text { risk }\end{array}$ & $\begin{array}{l}95 \% \text { confidence } \\
\text { interval }\end{array}$ & $\begin{array}{l}\text { Relative } \\
\text { risk }\end{array}$ & $\begin{array}{l}95 \% \text { confidence } \\
\text { interval }\end{array}$ \\
\hline \multirow[t]{4}{*}{ Activity } & employed & 1 (ref.) & & 1 (ref.) & & 1 (ref.) & \\
\hline & unemployed & 0.91 & 0.87 to 0.94 & 1.04 & 0.99 to 1.09 & 1.03 & 0.97 to 1.09 \\
\hline & studying & 0.65 & 0.62 to 0.69 & 0.73 & 0.68 to 0.77 & 0.77 & 0.72 to 0.82 \\
\hline & non-active & 1.00 & 0.96 to 1.03 & 1.20 & 1.14 to 1.25 & 1.27 & 1.21 to 1.33 \\
\hline \multirow{4}{*}{ Earnings } & none & 1.01 & 0.97 to 1.05 & 0.97 & 0.93 to 1.02 & 0.98 & 0.94 to 1.03 \\
\hline & low & 1 (ref.) & & 1 (ref.) & & 1 (ref.) & \\
\hline & medium & 1.14 & 1.10 to 1.17 & 1.13 & 1.09 to 1.17 & 1.12 & 1.08 to 1.16 \\
\hline & high & 1.36 & 1.31 to 1.41 & 1.26 & 1.20 to 1.32 & 1.24 & 1.18 to 1.30 \\
\hline \multirow{4}{*}{$\begin{array}{l}\text { Level of } \\
\text { education }\end{array}$} & lower secondary & 1 (ref.) & & 1 (ref.) & & 1 (ref.) & \\
\hline & upper secondary & 1.25 & 1.21 to 1.30 & 1.27 & 1.22 to 1.32 & 1.27 & 1.22 to 1.32 \\
\hline & lower tertiary & 1.54 & 1.47 to 1.60 & 1.52 & 1.46 to 1.59 & 1.53 & 1.46 to 1.59 \\
\hline & upper tertiary & 1.75 & 1.66 to 1.85 & 1.70 & 1.61 to 1.80 & 1.74 & 1.64 to 1.84 \\
\hline \multicolumn{2}{|c|}{ Months employed } & & & & & 1.009 & 1.005 to 1.013 \\
\hline \multicolumn{2}{|c|}{ Months unemployed } & & & & & 1.012 & 1.005 to 1.019 \\
\hline
\end{tabular}

Notes:

1. Basic Models include the woman's age, age of first child, calendar year, and the variables in the table one at a time.

2. Model 1 includes the woman's age, age of first child, calendar year, activity, earnings, and level of education.

3. Model 2 includes the woman's age, age of first child, calendar year, and all variables in the table. 
Table $6 \quad$ Relative third-birth risks by activity, earnings and level of education

\begin{tabular}{|c|c|c|c|c|c|c|c|}
\hline \multirow[t]{2}{*}{ Variable } & \multirow[t]{2}{*}{ Category } & \multicolumn{2}{|c|}{$\begin{array}{c}\text { Basic Models } \\
\text { (separate model for each } \\
\text { listed variable) }\end{array}$} & \multicolumn{2}{|c|}{ Model 1} & \multicolumn{2}{|r|}{ Model 2} \\
\hline & & $\begin{array}{l}\text { Relative } \\
\text { risk }\end{array}$ & $\begin{array}{c}95 \% \\
\text { confidence } \\
\text { interval }\end{array}$ & $\begin{array}{l}\text { Relative } \\
\text { risk }\end{array}$ & $\begin{array}{l}95 \% \text { confidence } \\
\text { interval }\end{array}$ & $\begin{array}{l}\text { Relative } \\
\text { risk }\end{array}$ & $\begin{array}{l}95 \% \text { confidence } \\
\text { interval }\end{array}$ \\
\hline \multirow[t]{4}{*}{ Activity } & employed & 1 (ref.) & & 1 (ref.) & & 1 (ref.) & \\
\hline & unemployed & 1.12 & 1.06 to 1.19 & 1.15 & 1.08 to 1.22 & 1.06 & 0.98 to 1.15 \\
\hline & studying & 0.71 & 0.65 to 0.79 & 0.72 & 0.65 to 0.79 & 0.71 & 0.64 to 0.78 \\
\hline & non-active & 1.22 & 1.17 to 1.28 & 1.26 & 1.20 to 1.34 & 1.27 & 1.20 to 1.34 \\
\hline \multirow{5}{*}{ Earnings } & none & 1.11 & 1.05 to 1.18 & 1.05 & 0.99 to 1.11 & 1.04 & 0.98 to 1.10 \\
\hline & low & 1 (ref.) & & & & & \\
\hline & medium & 0.94 & 0.90 to 0.99 & \multirow{2}{*}{\multicolumn{2}{|c|}{$\begin{array}{l}1(\text { ref }= \\
\text { low }+ \text { medium }+ \text { high })\end{array}$}} & \multirow{2}{*}{\multicolumn{2}{|c|}{$\begin{array}{l}1(\text { ref }= \\
\text { low }+ \text { medium }+ \text { high })\end{array}$}} \\
\hline & high & 1.02 & 0.97 to 1.08 & & & & \\
\hline & very high & 1.30 & 1.17 to 1.43 & 1.12 & 1.01 to 1.23 & 1.12 & 1.02 to 1.24 \\
\hline \multirow{4}{*}{$\begin{array}{l}\text { Level of } \\
\text { education }\end{array}$} & lower secondary & 1 (ref.) & & 1 (ref.) & & 1 (ref.) & \\
\hline & upper secondary & 1.08 & 1.03 to 1.13 & 1.11 & 1.05 to 1.16 & 1.11 & 1.06 to 1.16 \\
\hline & lower tertiary & 1.26 & 1.19 to 1.33 & 1.31 & 1.24 to 1.38 & 1.31 & 1.24 to 1.39 \\
\hline & upper tertiary & 1.56 & 1.44 to 1.69 & 1.62 & 1.49 to 1.77 & 1.63 & 1.50 to 1.77 \\
\hline \multicolumn{4}{|c|}{ Months unemployed } & & & 1.016 & 1.007 to 1.026 \\
\hline
\end{tabular}

Notes:

1. Basic Models include the woman's age, age of second child, calendar year, and the variables in the table one at a time.

2. Model 1 includes the woman's age, age of second child, calendar year, activity, earnings, and level of education.

3. Model 2 includes the woman's age, age of second child, calendar year, and all variables in the table. 


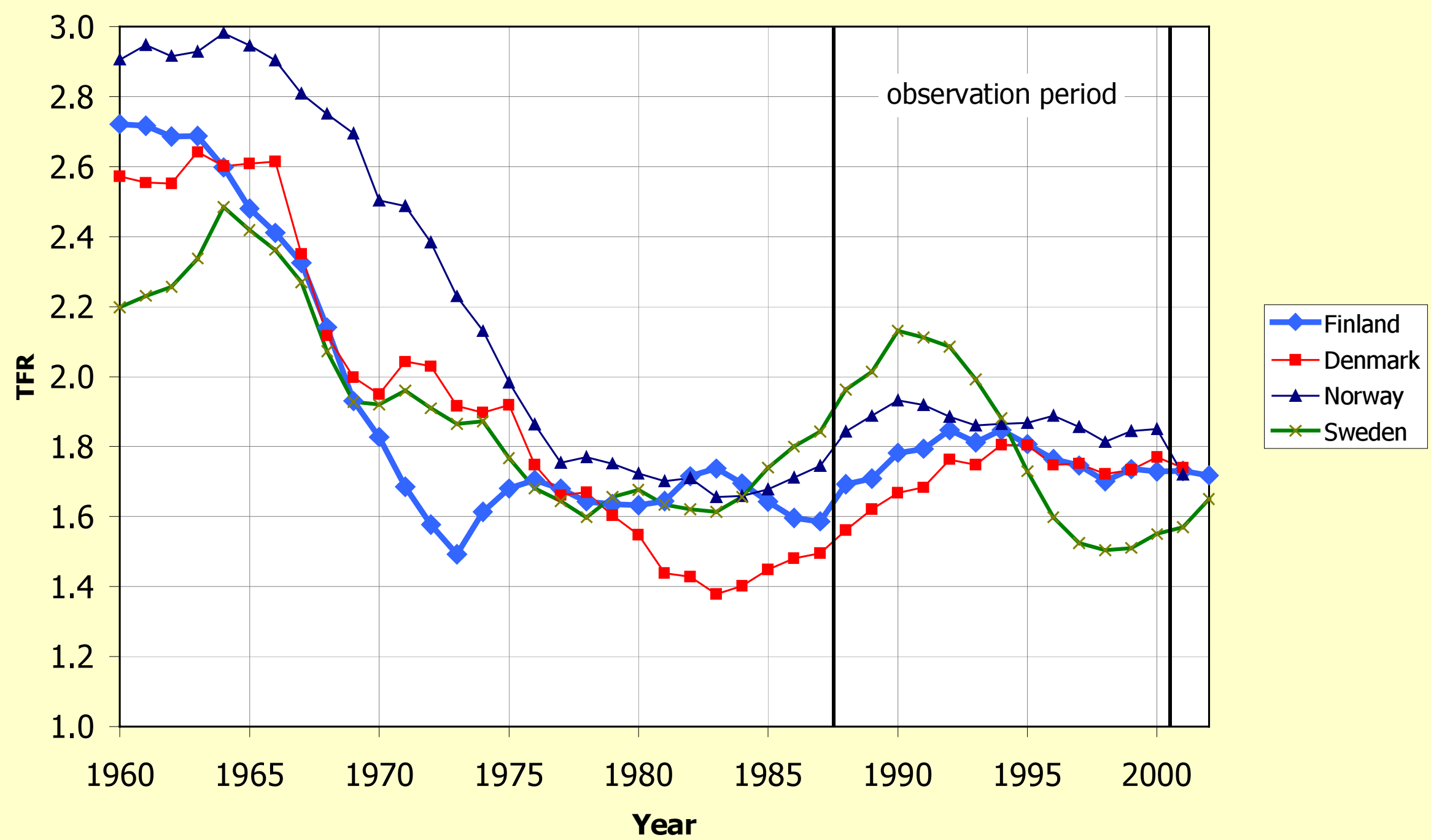

Sources: Council of Europe (2003) and national statistical offices of the Nordic countries. 

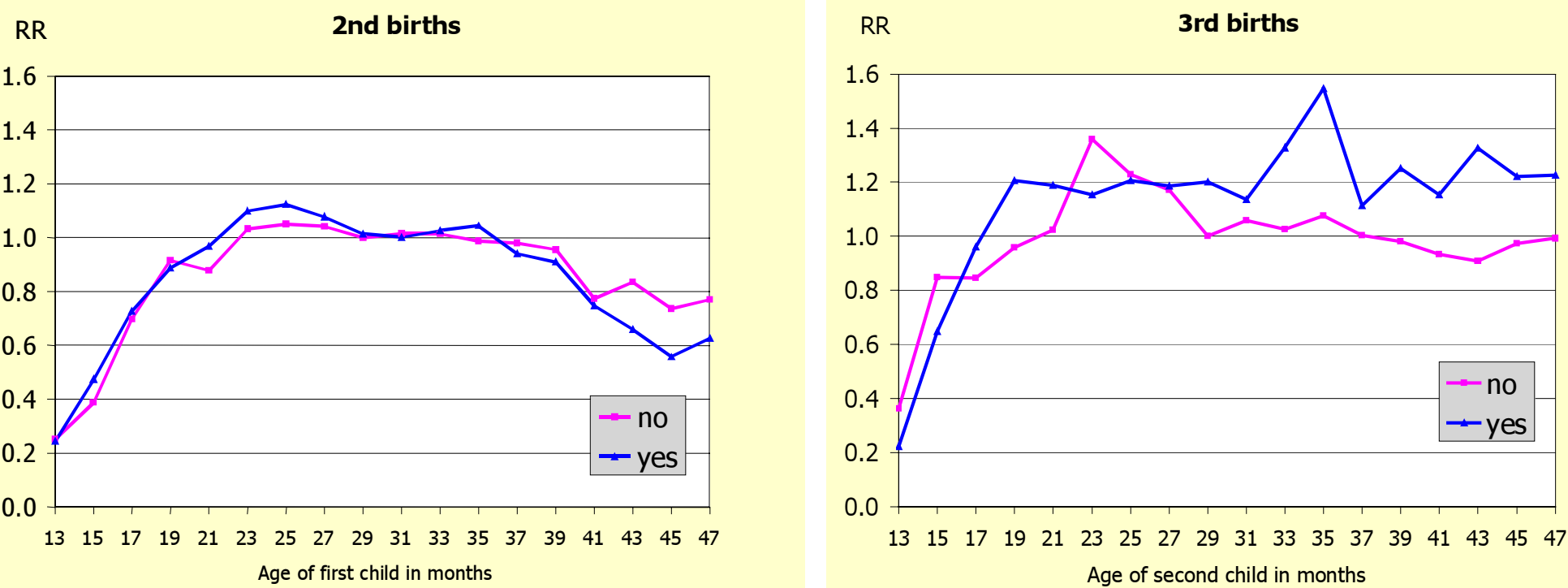

Notes: The curves are estimated from a hazard regression model that includes age, calendar year, and the interaction of age of youngest child (in two-month groups) and HCA use (defined as receiving any amount of HCA in the previous calendar year). The presented risks are relative to women whose youngest child is 28 to 29 months old and who did not receive HCA in the previous calendar year. In the models, exposure to the birth risk starts in January of the year during which the youngest child becomes two years old so that the mother could be entitled to HCA in the previous calendar year as far as her youngest child's age is concerned - and ends when the child becomes four. 
Figure 3 Relative birth risks by calendar year estimated from different hazard regression models

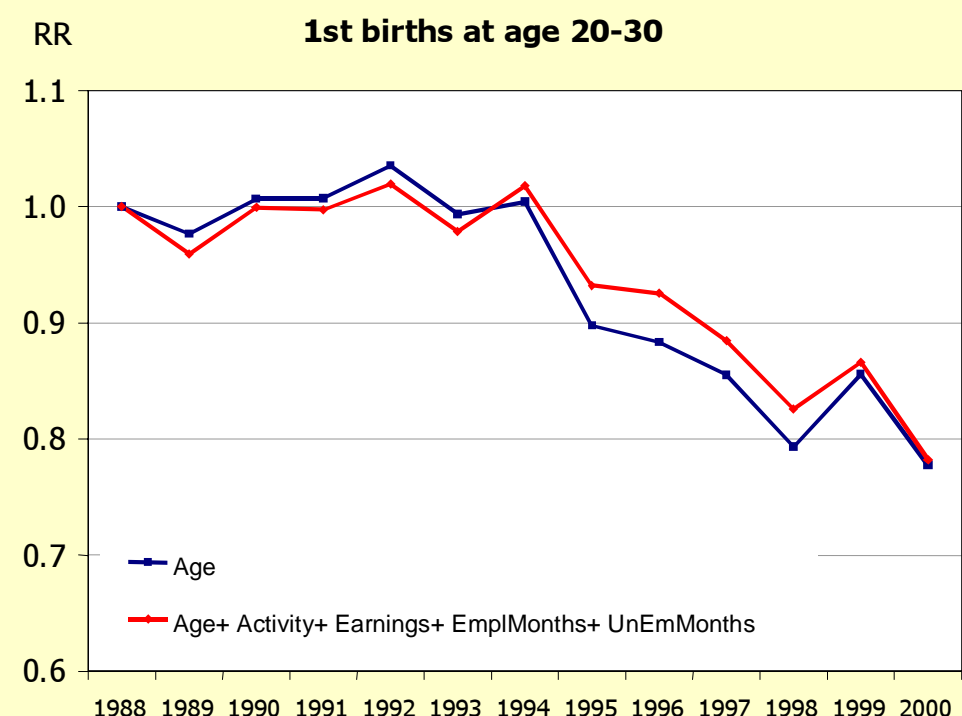

2nd births

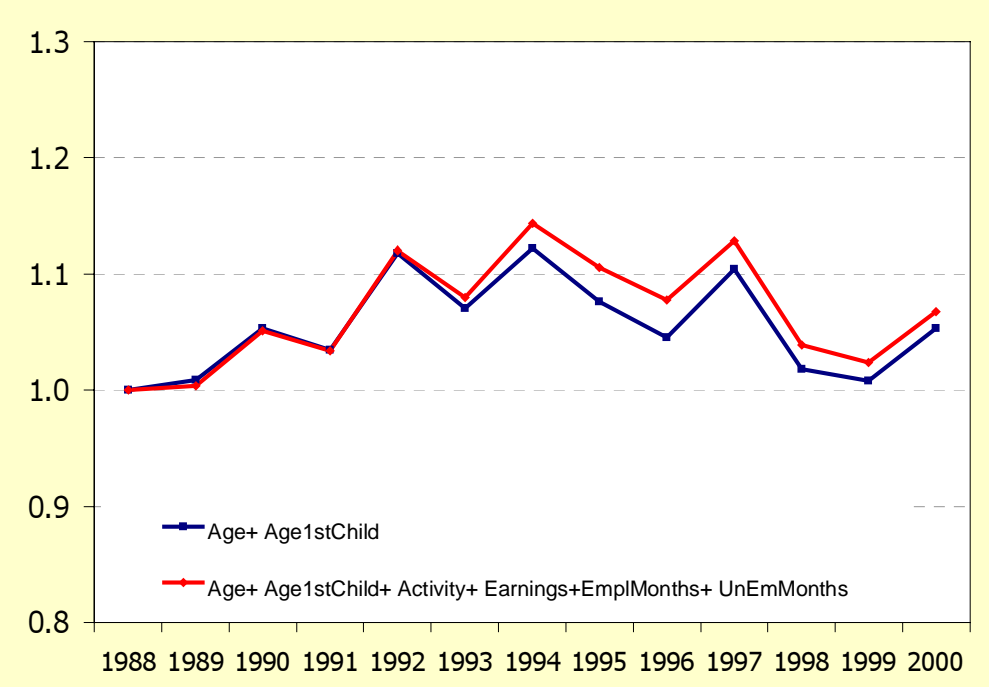

1st births at age $31-44$

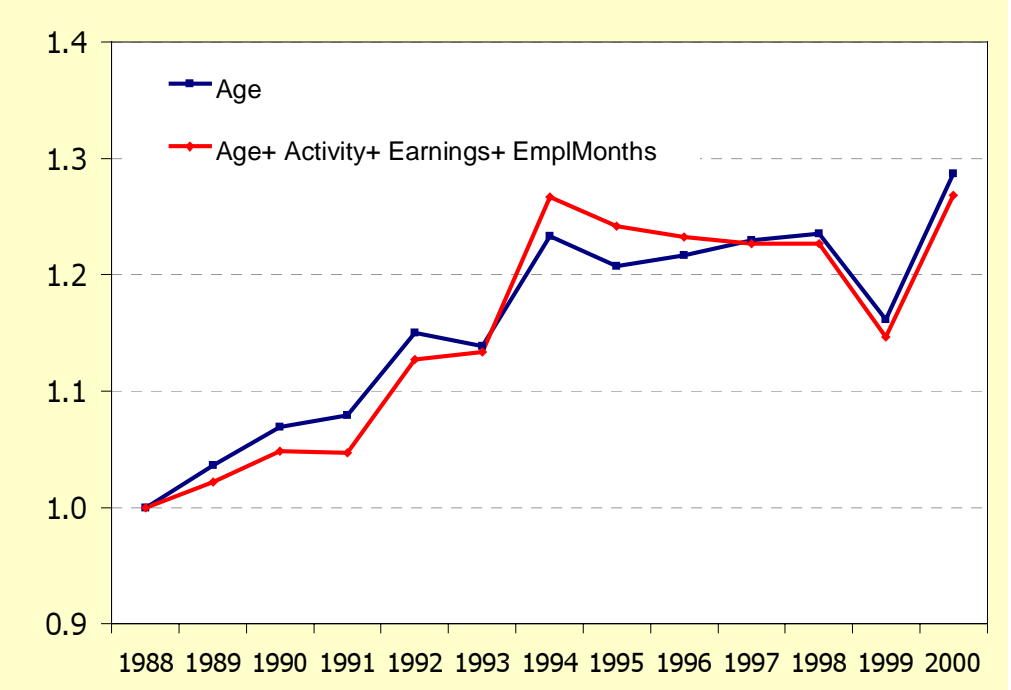

3rd births

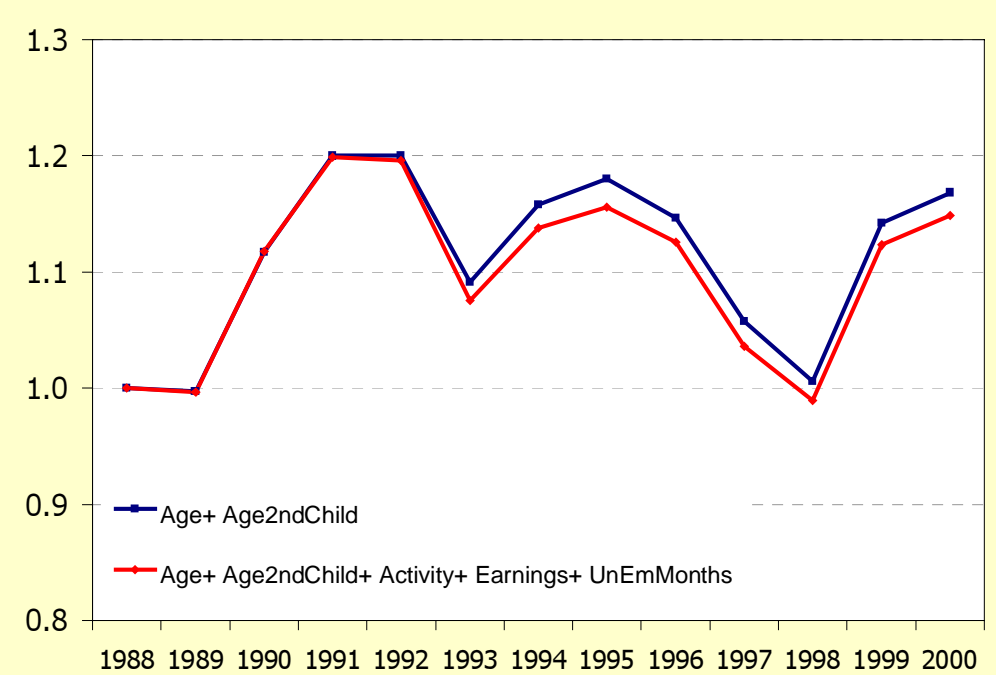

